Шедяков В. Е., д.с.н., к.э.н., доцент

независимый исследователь

г. Киев, Украина

DOI: https://doi.org/10.30525/978-9934-26-145-9-12

\title{
ЦЕННОСТНОЕ СТИМУЛИРОВАНИЕ ТРУДОВОГО ПОВЕДЕНИЯ
}

В процессе развития хозяйствования приходится иметь в виду как распространение стратегической неопределённости, усложняющей установление приемлемого горизонта планирований, так и изменение ценности элементов человеческого потенциала. Так, успешное перекладывание ряда рутинных энергоёмких и мускульных функций на агрегаты разного рода, позволяет персоналу сконцентрироваться вокруг творческой деятельности, сдвигающейся в центр общественного богатства. Повышение необходимой работнику квалификации, рост фондовооружённости рабочего места, акцентирование уникального, творческого труда и культивирование разумной инициативы и поиска обесценивает функции контролёра и администратора. И наоборот, те же процессы становятся мощными факторами подъёма роли стимулирования и непрямых методов воздействия, в т.ч. ценностного стимулирования [1-5].

Межпарадигмальный переходный период предрасполагает к поиску оптимальных социально-экономических решений и конкретных организационных форм, обеспечивающих достойное применение своего потенциала в конкурентной борьбе. Как известно, хаос и кризис расширяют коридор возможностей, сужающийся при выработке обновлённого порядка. Понимание логики истории неизбежно приводит к осознанию необходимости кардинальных трансформаций. Но вот их содержание, задачи, a, стало быть, избираемый инструментарий, ближайшие и дальнейшие последствия заметно разнятся. Между тем, повсеместное закономерное усиление «левой повестки» выносит в число определяющих образ возникающего облика ойкумены вопрос о 
её доминирующем векторе и формах. В частности, будут они направлены на «отобрать и поделить» и борьбу за присвоение привилегий или же приоритетно включат производственный базис и возможности созидать?

Другими словами, станут ли её символом жизненные ценности иждивенца или творца, обывателя или созидателя? А ведь разрыв между технико-технологическим ростом и нравственно-духовным развитием не только губителен для всякой биосоциальной целостности, но и смертельно опасен для окружающих, ныне, при глобальных масштабах взаимосвязей и возможностей, - для всей ойкумены. Так, призвание людей - в самовоплощении: биологическом, по-звериному (в потомстве), социальном (в общественных формах), в приближении к божественному (в создании идей и смыслов). И непременным условием воспроизводства трудового потенциала становится со-творчество в обществе и понимание своего долженствования и миссии: если для простого труда социальность принудительна как участие в разделении труда, то для труда уникального - творческого - общественный характер непосредственно входит в его существо (при том, что само творчество - активность в развитии / реализации сугубо индивидуального комплекса одарённостей). Соответственно осуществляются процессы репродуцирования и продуцирования. Между тем, создание и распространение ценностных характеристик бытия непосредственно связано с полноценностью мышления, развёртыванием его всеобщих форм, реализацией в социокультурной жизни пластов идеального. Базовые ценностносмысловые комплексы и основанная на них нравственность уничтожимы только вместе с самим народом. Как известно, отнюдь не всякие ценности и идеалы обеспечивают надёжную опору для твёрдых убеждений, нравственного и цельного мировоззрения. Аксиологическая функция сознания участвует в выработке общественных норм и традиций, не только осуществляющих важнейшую регулятивную миссию, но и обеспечивающих. Причём если утилитарно-прагматические ценности производны от способа производства непосредственно либо через 
структуры потребностей, то абсолютные ценности влияют на воспроизводство условий жизни как исходные [6-9].

Возвращение сознания к его нравственным истокам - учению о праведной жизни - непременное условие преодоление иррационализма общественными отношениями и политическим режимом, необходимость и осмысленной реализации жизненной стратегии, и сознательной гражданской активности. Как известно, изначальный фундамент нескончаемой глобальной кризисности - аморализм и отход от высших нравственных идеалов, ценностей и принципов (в частности, актов деятельного самопожертвования и сострадания). Между тем, всё поистине дорогое не имеет цены. Содержательные, в т.ч. лучшие / важнейшие понятия никак не связаны с капиталообразными формами и не могут быть капитализированы. Далеко не всё решается деньгами и имеет денежное измерение. Так, высвобождение ценностей творчества из-под спуда капиталообразных форм - элемент преодоления патологизации и иррационализации мира, а соответствующий вектор ценностного стимулирования его эффективный механизм. Напротив, если от ценностей напряжённого труда и достижений массово переходят к ориентациям на идеалы либо быстрого обогащения (желательно, нетрудового), либо обывательские, мещанские - «лёгкого хлеба» и концентрации на развлечениях, то для биосоциальной общности наступают серьёзные проблемы. Тогда деквалификация оказывается реальностью и ведущим вектором изменений. Падкими на тот или иной вариант «лёгкого хлеба» легко манипулировать; они заведомо несамостоятельны. Успешными становятся в первую очередь те культурно-цивилизационные миры, которые в состоянии не только заинтересовать, увлечь своими смыслами, но и структурировать своё социальное пространство, применяя при этом и классические и инновационные ресурсы, интегрируя базисные для себя формы ценностного сознания с логикой исторических изменений и особенностями ценностной ситуации. Очутившись не на той стороне истории, трудно удержаться от искушения упрощенного 
понимания происходящего. Между тем, производное от него насилие над народом не только тщетно по своей безрезультатности, но и глубоко аморально по сути.

\section{Литература:}

1. Франкл В. Человек в поисках смысла. Москва : Прогресс, 1990. 368 с.

2. Томашкевич В.Е. Трудовая активность. Москва : Экономика, 1985. 208 с.

3. Шедяков В.С. Економічна свобода і духовно-ціннісна консолідація: завдання якісного соціального управління. URL: http://ua-ekonomist.com/6434ekonomchna-svoboda-duhovno-cnnsna-konsoldacya-zavdannya-yaksnogo-socalnogoupravlnnya.html.

4. Шедяков В.Е. Ценностные основания национальных моделей социальноэкономического развития. National Economic Reform: experience of Poland and prospects for Ukraine / ed. by A. Pawlik, K. Shaposhnykov. Kielce : Baltija Publishing, 2016. Vol. 2. P. 164-190.

5. Шедяков В.Е. Ценности в зеркале стратегической футуродиагностики. Науково-теоретичні аспекти вирішення глобальних проблем сучасності : Матер. Міжнар. наук.-практ. конф. Дніпропетровськ, 2015. С. 136-139.

6. Mitchell R., O’Neal M. Managing by values (is Levi Strauss' approach visionary - or flaky?). Business Week. 1994. Aug., 1. P. 46-52.

7. Шедяков В.Е. Ценностное стимулирование как форма гибкого управления. Сучасна украӥнська держсава: вектори розвитку та шляхи мобілізаиії ресурсів : Матер. Міжнар. наук.-практ. конф. Одеса, 2016. С. 222-226.

8. Шедяков В.Е. Ценностное стимулирование в осуществлении стимулирования желательных трансформаций. Сучасні тенденції в економіці та управлінні: новий погляд: Матер. IX Міжнар. наук.-практ. конф. Ч. III. Запоріжжя, 2015. С. 59-62.

9. Шедяков В.Е. Ценностное управление в реализации социокультурной основы институциональных трансформаций. Актуальні тенденції розвитку суспільних наук у Украӥні : Матер. Міжнар. наук.-практ. конф. Київ, 2015. C. $90-93$. 